\title{
Minimum and maxinum magnitude threshold in the area of Attica; Greece
}

\author{
A. G. GaLANopotros (*) \\ Ricevuto il 19 Genuaio 197
}

\begin{abstract}
Sumakr. - The "once per Fear" earthyuake $H$ is a more reliable meanure of keismicity than the constant a of the $N(M)$-relation. The "ance per year" earthquake $y$ is controlled by the period of olwervation mouch less than the constant a. Seismicity derived from a sample of a short period of observalion inaderiate at the largest magniturles may lis at least half as mon smaller than that we get from a sample complete over all shocks recorted in a long period of observation. The lower bending of the straight lines representing curves of the form $\log N=a-b .1$ is contitioned by the thetection thresholf. The maximum magnitude thresholt is time depentent. Shoclis associater with olt, transwerse doep-seated lineaments in the area of treece are relatively greater but less fretuent than those genetically connectot with longiludinal struchural fentures of the area.
\end{abstract}

Russisto, - La H relativa all" once per year enthquate" ì ma misura di sismicitia più sicura di quanto non lo sia la coslante a della re-


jer un periodo di osservazione molto piǹ piecolo di quello usato per la co.


insufficiente per le piò grandi marnitudo, puo esisere pin piccola di almeno la meta sli quella ricavala da un periodo campione conpleto. conprendente tutte le scosse registate durante un hungo areo ti tempo. Ta minore in. clinarone telie linee rette che rappresentano arve tella forma log $N$ : $a-b . .$. . è contlizionata talla soglia di intlviduazione ti . . Ta soglia in corrikpontenza del massimo tella magnitudo dijende dal tempo. Te seosse associnte ai lineamenti trascersali, inserliati in profonditio nella tona dellat Gresia, sono relativamente jii granti, ma meno frequenti di quello reneti camente lesate ai linenmenti struthrali longitudinali tolla zona stessa.

(*) J)irertor of National (Blservatory of Athens. Neismologiral Institute. Athens (Greace). 




liartliquake secpuences are well known to (xhibit the relationslip' $\log N=a-b M$, where $N$ is the number of eartlaquakes witl magnitude greater than or equal to $M$, $a$ and $b$ are comstant for a partionlax secquence.

The parametey a depends on the level of the reisunis astivity fer unit area and unit time and varies therefore from sequence to sedpuence acotording to the size of the mea involved and the perlod of observation $(7,8)$.

There is evidense tluat the parameter b depends lawgely on the stress, the strength and the homogeneity of llue rorkis in the fortal area $(15,21)$, or the averago foeml depth of the earthquakes considered $\left({ }^{6,9}\right)$. The reported values of $b$ usually lie between 0.5 and $1.5(7)$, but for a given geotoretonis nuit there is no matked rlange of $b$ with the time or tlee number of shoreks $\left(6,14,1^{9}\right)$.

The lineal relationship axpressed by the foresabl equation holds for every rextion, small or latre, but for slocks of a certain magnitude mange. The number of shooks below the minimum and over the maximum manditude tlueshold for a given aren is loss than expected from extrapolatiug the log $N$ versus $M$ curvo.

The unininum as well as the maximum masnitude threslobld for at criven area is stromgly related to the stress late and the merlamiond


the minimum and the maximum magnifude threshold for a given atom might bo a seismic feature of the area.

In most regions of the Earth the return periods of major earthquakes are very long and the maximum manitule threshold apposuch in relatively slort periods of observation eamot the afeature of the regrion. Time samples of greater that 500 to 1000 years are nexessary to esstublish the upuer limeit (5).

On the aontrary, the return periods of minor sloocks abe grenerally slort and the minimum magnitude threshold of a given region observed in relatively short periods of observation might be a foublue of the regrion. It is, lowever, to be noted, that the minimum magnitude threshold observed in a griven area derpends a groat deal on the sensitivity of the sejomograplss and the umber of observing stations in the anes. Under these conditions it is labre to say that the minimum




of the region, auless whatever increaso in sensitivity of tlos seismograplic: stations does not result in lowering the level of the observed limit.

In the presont pander and atempt is male to find ont if the minimum

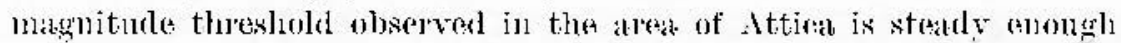
to be cousidered a feature of the ares. The return periorls of major astheuakes in the area of Attima are tow loner $\left(^{6}\right)$ to allow a reliable determination of the maximm magnitude fluresleold that could los another festure of the areal.

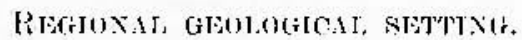

The area under investigation is located on tha northwost margin of the Attie- yoladic MLassil. The ase of tle arystalline rock series ranges from pre-cioboniferous to Middle-('arboniferous (16), and oc:ationally up to Cretabens (12). The crystalline basement is mononformably overlain by Lpper Palneozoic kedimentaty rocks. The MLesozois: sediments are represented by the Triassir: system and lie nucoulformably on tlie Pablacozoja sedimants (11).

The northern end of the Attic-cyclaclie MLassif represents the metamorphice continuation of the eastern IHollenie Zone (3.13). The (rystalline basmuenti is the (ommon had ane of all the sedimentary series of eastern Greece.

The rastern Ifellenice Zone, alio linown as Sabpelagonic Zone. surrounds the Attic-cyladis: Massif of the Pelogonie Zone. The Subpelagonis: Zone, which onterops in most of the anviromments. (oonsists of metamorphosad and unmetamorphosed sedimentaly and voleanio

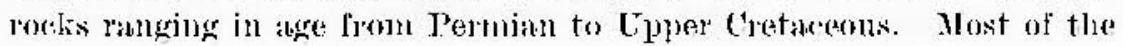
Zone is represented by a thick series of alternting kohists, whalstones, wherts and limestones interbedded witle albundant oplioblithice alfussives, and liperer ('retaceous flysell.

The Zome of Fordar is reprosestetesd in a smatl part of the areat


of Triaskie to Juraksio age.

Fig. I slows portions of threse oflese sedimentary series that partilipate in the fabric of the asea:

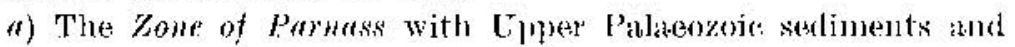
neritir: limestones ranging in age from Triassio; to Palanesents.

b) The Zone of Pindus with mostly abysad sediments of Triassi. to Eocene age. 


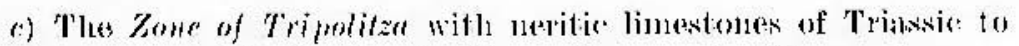

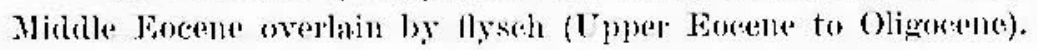

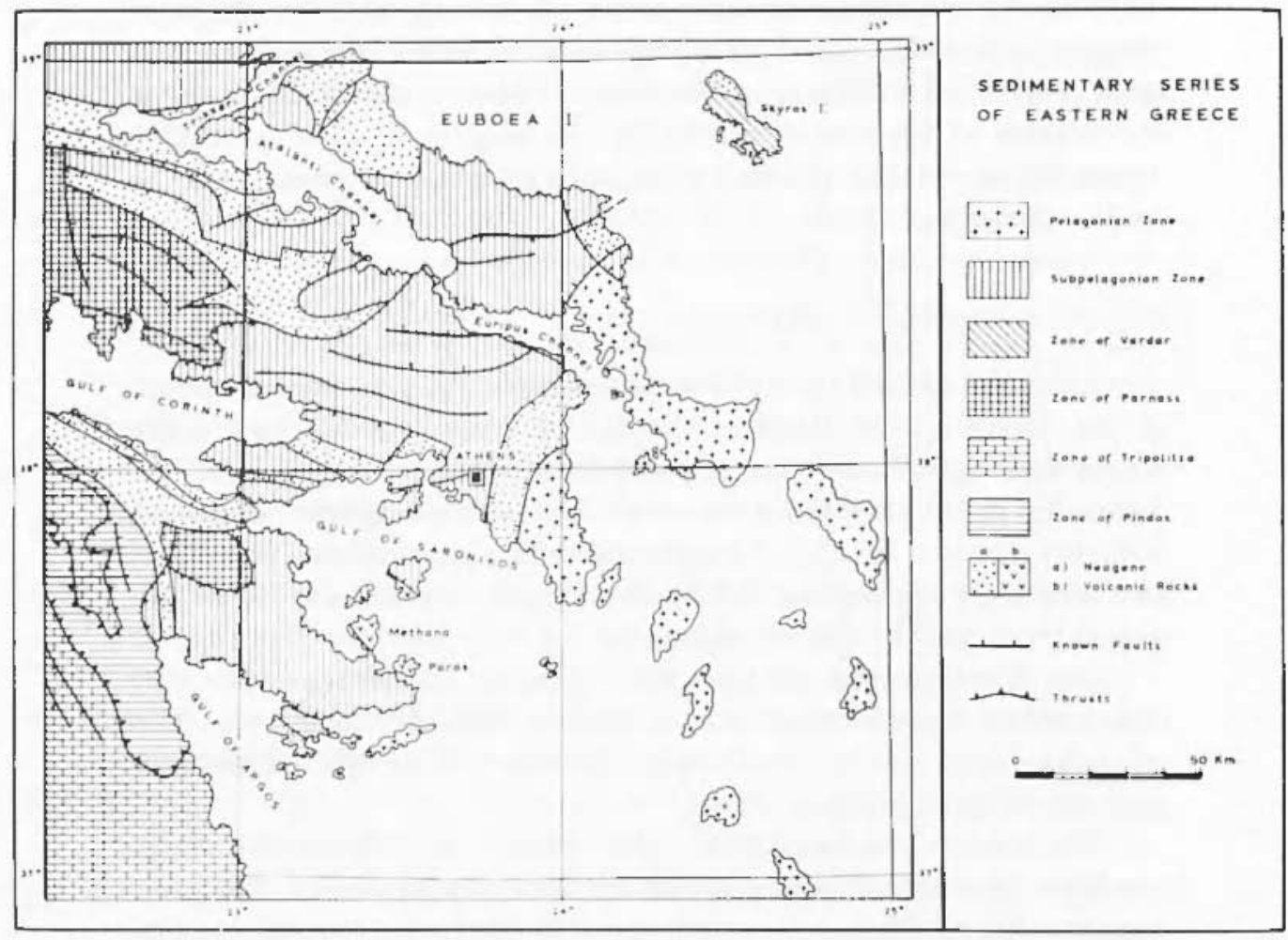

Fig. I - Sirnctural man of the major regrion of Attica, al'ter J. Burnovas $(1970)$





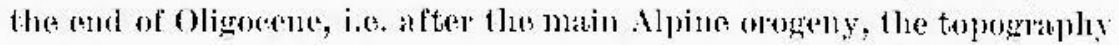
of the aretu was greatly altered by rifting and subsidence. The finlf

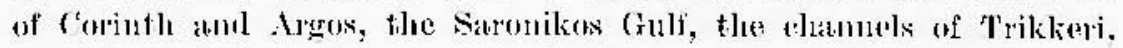
Alalanti amul Euripus, as well as the basins of Theves-liopais, dition, and Imoni-St. Anma in Fuboea Islaml wele fommed by Miocene and post-Mioneme dislocation. Sladlow partis of grabens, rift valleys, faultloumled baxims and elongate alosed depressions thus formed wore fillexl up ly interhanging strata of marly limestonos and marls of IIocene age as well as samdstomes and conglomerates of Plincene and 


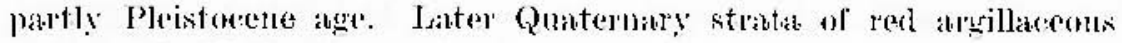

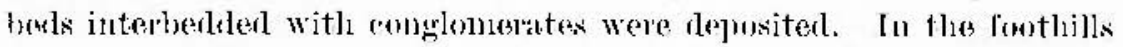
of the monutains the Alluvimu cunsists of loose sumd, pebbles and datiritus.



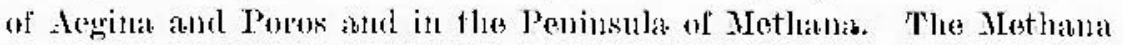
Volemo whs still active in 2 s.2 B.C..

Consirleralble dovelopment of vertical and strike-sli] faulting lou

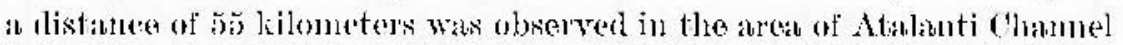

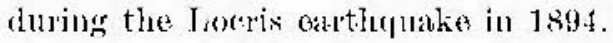

IIITA.

Data useal for the ande antlinerl sturly are listed in two Tables.

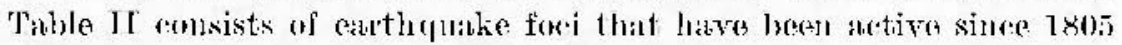

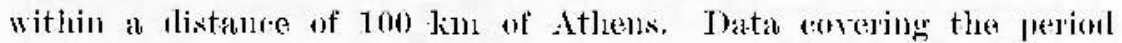
1805 to 1950 wase taken from a Talble publisherl by the autlou in 19ti3. The data of the perion 1951 to 1 \$is were taken from an nu-

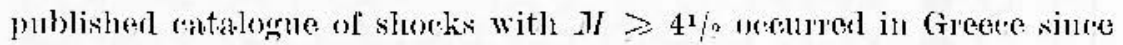


compiled from the eIscas arods of fureliminaty aleternimation of ('picienters's.


molourinal Stations Notwork witlin a distance of $100 \mathrm{~km}$ of Atlems over a 4-yem period, July 1965 through June 1964). The data were taken from tha montihly prelininary bulletins of Atletss. All magnitules


recordod by the stmolard Wood-Auderson instruments at Athens.





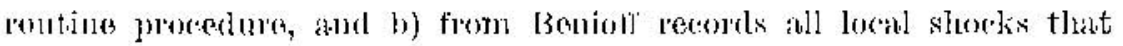
were missed from the recololings of tle Wood-sudersou instrumentis; the magnitures were chlculated fom the maximum trace amplitudes

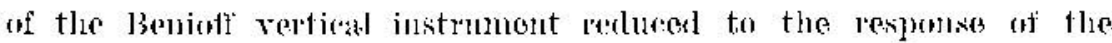

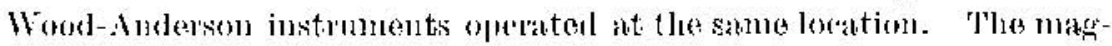

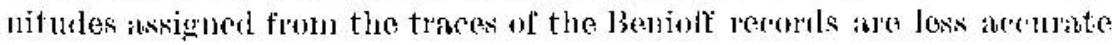

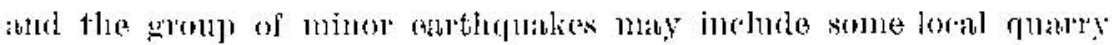
blasts. For lask of rown the catalogue of the supplemontary datat is not publislied. 
STITSTIC.

l)atia pror to 1 soj are spanse; therefore, statistins are limited to the period 1805-1969. During the 120-vear interval, 1805-1969, there were relensed form $5 \mathrm{i}$ fori, within a distance of $100 \mathrm{~km}$ from Athens,

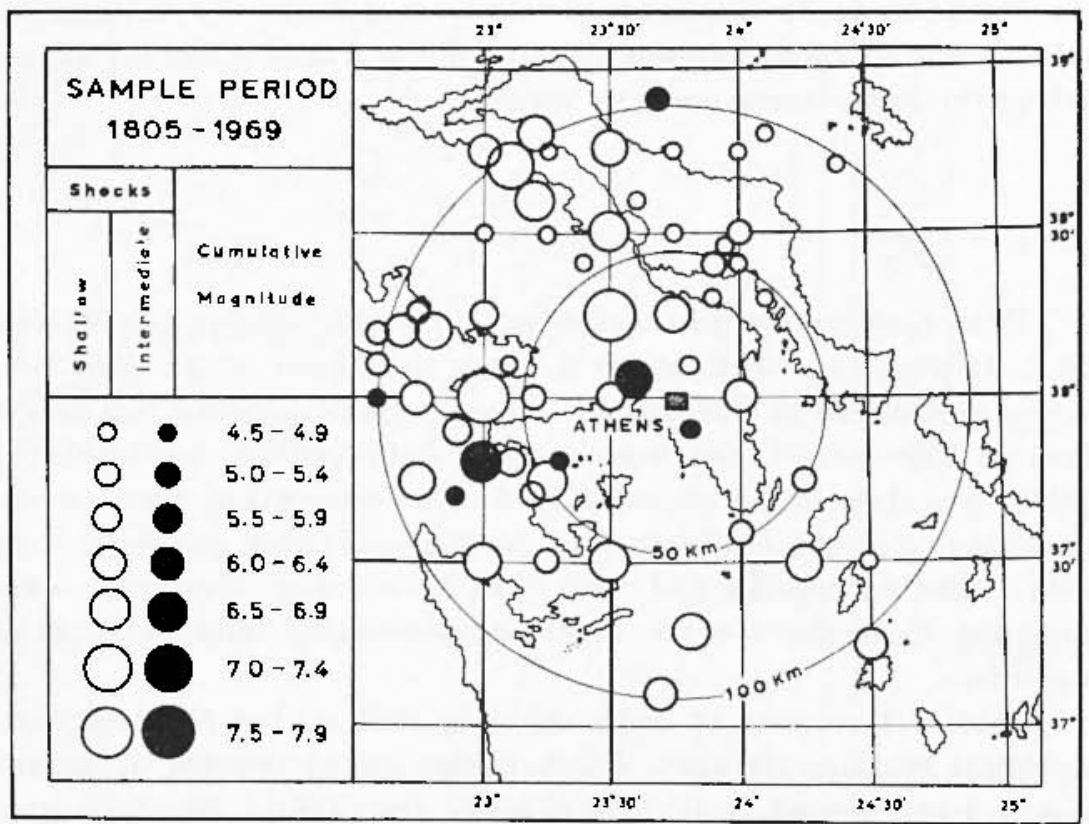

Fir. 2 - Earlhquake epiconter map of the major regrion of ittica for the period 1805.1969.

17 shocks with $M-1.5-4.9,27$ shueks with $U-5.0-5.4,18$ with $M=5.5-5.9,8$ witl $. I=6.0+6.4,3$ with $M=6.5-6.9,2$ with $M-7.0-7.4$ and 1 with $M=7.5-7.9$. In a tabular form we hava:

$\begin{array}{lccccccc}M & 11 / 2 & 5 & 51 / 2 & \pi & (i 1 / 2 & 7 & 71 / 2 \\ N_{1213} & 106 & 59 & 32 & 14 & 6 & 3 & 1 .\end{array}$

$\begin{array}{llllllll}N_{1} & (1.885 & 0.492 & 0.26 \mathrm{iT} & 0.116 & 0.050 & 0.025 & 0.008\end{array}$ $\log N_{1}-0.059-0.310-0.574-0.933-1.301-1.002-2.078$

where $S_{120}$ and $S_{1}$ is the number of shorlss of misguibule $M$ or greater 
in 120-you period and per' one yent, respertively. 'Tluese values dit: rether clusely to

$$
\log N_{1}-(3.05 \pm 0.11)-(0.67 \div 0.016) M \text {. }
$$

If wo thop the values for $M<5^{1 / 2} / 2$ we tind:

$$
\log N_{1}=(3.53 \pm 0.12)-(0.74 \div 0.03) . M .
$$

'The libting is belter, bet lle clinnge of $b$ is within the limits of error. If we take into eonsideration only the shockis with $H \geqslant 4 / 2$ oceured witlin a distanco of $100 \mathrm{~km}$ from Athens during the periol 1930-1969, we have 32 shocks with $M=4.5-4,9,13$ with $M=5 .(1-5.4,9$ with $M=5.55-5.9,1$ with $M=6.0-4.1$ and 1 with $M=6.5-1 ; .9$. If we denote by $N_{40}$ and $N_{1}$ the number of slocks of magnitude $M$ or greater in so-year period and per one yeur, respectively, we have

$\begin{array}{lcccll}M & 51 / 2 & 5 & 51 / 2 & 6 & 6^{1 / 2} \\ N_{40} & 56 & 24 & 11 & 2 & 1 \\ N_{1} & 1.10 & 0.60 & 0.275 & 0.050 & 0.0255 \\ \log N_{1} & 0.11 & -0.20 & -0.56 & 1.30 & 1.60\end{array}$

'Tlue data for this period fit to

$$
\left.\log N_{1}=(4.601+0.78)-(1.00 \pm \pm .08) \mathrm{m}\right) .
$$

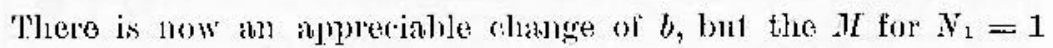
is witliju the linits of enror.

During tho A-year period, July 1965 throngh June 1969, 1lere have been antive 103 fore witlin a dislance of 100 kn of thens: these ford releused .1 shosks will $1 Y=1.0-1.4,10$ with $M=1.5-1.9$, 9 with $M=2.0-2.1,71$ with $M=2.5-2.9,816$ will $M=3.0-3.4$, 32 witl $_{1}, I=3.5-3.9,5$ with $, K=1.0-1.1,2$ with $M=1.5-4.9$ and 1 with $M=5.0-5.1$. Jikndedins the shorks with $M<21 / 2$. wo linve:

$\begin{array}{lcccccc}M & 21 / 2 & 3 & 31 / 2 & 4 & 11 / 2 & 5 \\ N_{4} & 197 & 126 & 10 & 8 & 3 & 1 \\ N_{1} & 49.3 & 31.5 & 10 & 2 & 0.75 & 0.25 \\ \log N_{1} & 1.69 & 1.50 & 1,(H) & 0.30 & --(1.125 & --0.130\end{array}$

'l'lue rallues lit to

$$
\log \Lambda_{1}=:(1.30 \pm(1.18)-(0.9 n: \perp(1.019) . y
$$


If we take info account the slocks missed during the routine procedure

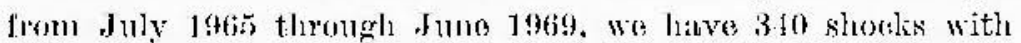

$M=1.0-1.4,138$ with $. M=1.5-1.9,218$ with $M-2.0-2.4$, 2.21 with $H-2.5-2.9,102$ with $_{1} M=3.0-3,4,34$ with $. M=3.5-3.9$, 5) with $H=4.0-4.4$, 2 with $Y=4.5-4.9$ and 1 with $M-5.0-5.1$. Discededing the shorelis witl $M<2$, wo have:

$\begin{array}{lccccccc}M & 2 & 21 / 2 & 3 & 31 / 2 & 4 & 41 / 2 & 5 \\ N_{1} & 613 & 365 & 14-2 & 42 & 8 & 3 & 1 . \\ X_{1} & 153.5 & 91.2 & 36 & 10.5 & 2 & 0.55 & 0.25 \\ \log N_{1} & 2.19 & 1.96 & 1.56 & 1.02 & 0.30 & -0.12 .3-0.60\end{array}$

Sample Period 1965, July 1 Through June 30,1969

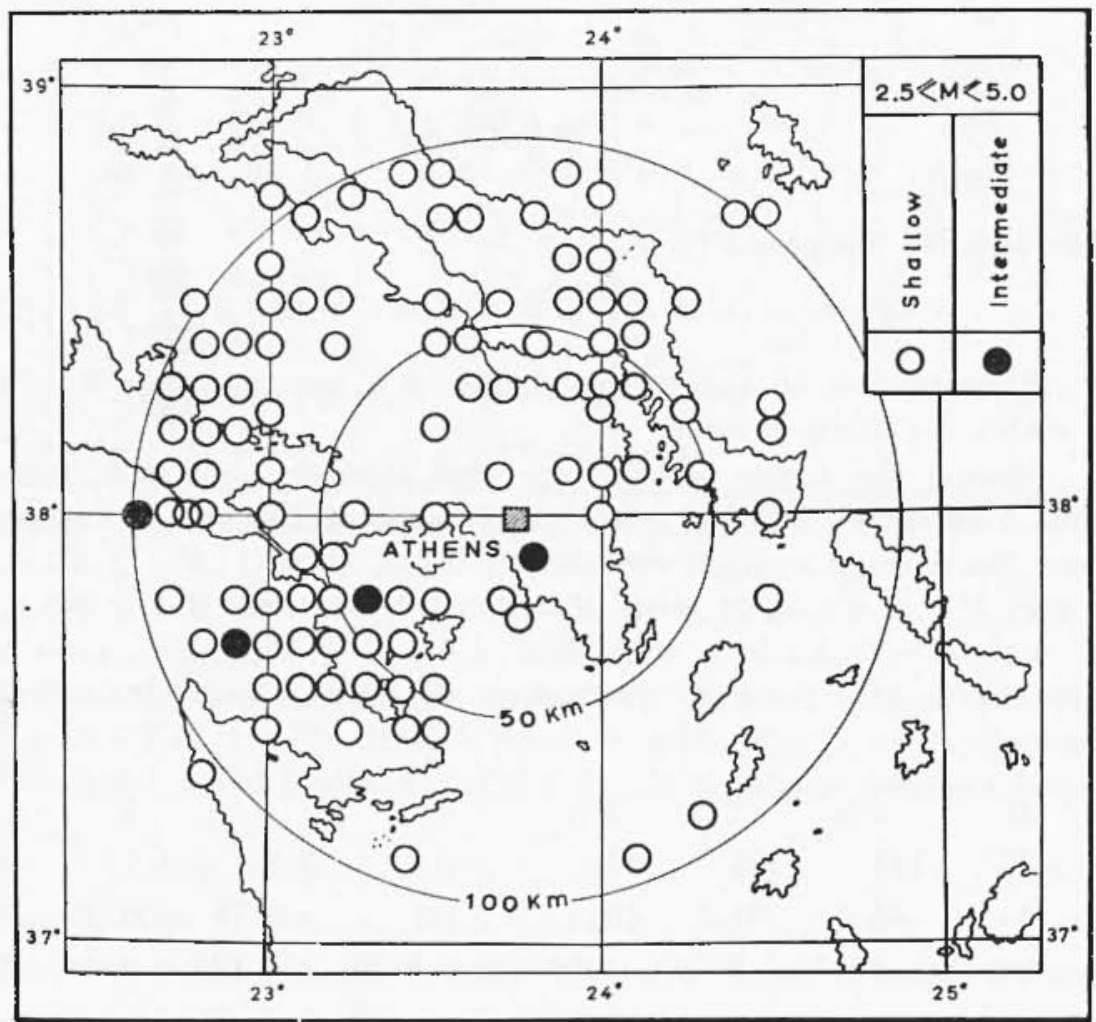

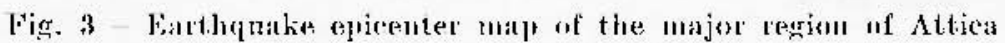
for the period 1965-196!. 
The alsove values fit to

$$
\log N_{1}=(4.34 \pm 0.16)-(0.98+0.09) . M \text {. }
$$

The mininam thresleold of the $\mathrm{S}(. / \mathrm{H})$-relation was lowered by one latl' anit withont alange of the a and $b$ coustants.

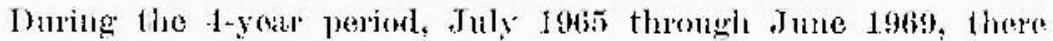
hilve been astive 31 fore within a distance of $50 \mathrm{~km}$ of Athens; tloset fori relowsed \& shorks will $. K=1.0-1.4,9$ with $. M=1.5-1.9$, 6 with $H=2.0-2.1,17$ with $U=2.5-2.9,11$ with $M=3.0-3.4$, 5 with

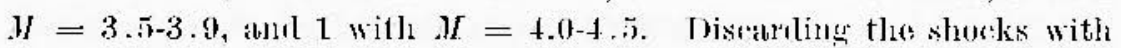
H $<21 / 2$, we liave

$\begin{array}{lllll}M & 21 / 2 & 3 & 3 \% & 4 \\ N_{1} & 34 & 17 & 13 & 1 \\ N_{1} & 8.50 & 4.25 & 1.50 & 0.25 \\ \log N_{1} & 0.94 & 0.633 & 0.17 & -0.60\end{array}$

The ralues romespond to

$$
\log S_{1}=(3.6 x \pm 0.2 s)-(1.04 \pm 0.10) \mathrm{H} .
$$

Traking into anomat the slocks missed during the routine procetures

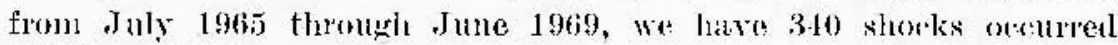
witlin in distanee of $50 \mathrm{~km}$ from Atlens will $M=1.0-1.4,137$ witl $M=1.5-1.9,95$ with $M=2.0-2.4,34$ with $J=2.5-2.9,11$ with $M=3.0-3.4,5$ witl $M=3.5-3.9$ and 1 with $M=1.0-4.4$. Jyisciul-

\begin{tabular}{|c|c|c|c|c|c|c|}
\hline II & $11 / 2$ & 2 & 219 & 3 & $31 / 2$ & 4 \\
\hline$N_{1}$ & $2 \times 1 ;$ & 1.14 & 5.1 & 20 & B) & 1 \\
\hline$N_{1}$ & $\overline{1} 1.5$ & 37.2 & 13.5 & 5 & $1.50)$ & 0.25 \\
\hline $\log X_{L}$ & 1.85 & $1.5 \overline{1}$ & 1.13 & 0.70 & 0.18 & -0.60 \\
\hline
\end{tabular}
ing tle shouks with $M<11 / 2$, we liave:

The new values (eorrespoul to

$$
\log N_{1}-(3.50 \pm 0.20)-(0.96 i=0.11) . \% \text {. }
$$

Sow the minimum threshold of the $N(M)$-relation was luwered by one

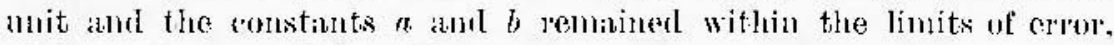
without clarge ol.$I f$ for $X_{1}=1$.

In tha rase of the locitable slocks during the pontine procedure the $N$, for $M=0$ is about I times greater willnin 100 km than within 
$50 \mathrm{~km}$ from Athous. It is supprising that in the cuse wo take into ac:comt the missing shoreks the $N_{1}$ for $I I=0$ is about 7 times greater within $100 \mathrm{~km}$ than within $50 \mathrm{~km}$ from Athens. The discrepansy is removed if wo rlop the shocks with $M<2$. In that maso we labve:

$$
\log N_{1}=(3.75+0.19)-(1.05 \pm 0.10) H .
$$

'l'here is no markod cluango in tho slope, but the $N_{1}$ for $I I \ldots 0$ is now again about 4 times greater within $100 \mathrm{~km}$ than within $50 \mathrm{~km}$ from ithens.

I'aking into aceount the earthquakes missed from the recordings of the Wood-Anderson instruments, the local shocks detectable at Athens over the perior July 1965 through Jumo 1969 may be written in inerements of $0.5 \mathrm{n} M$ as follows:

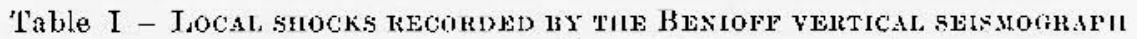

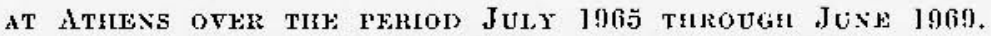

\begin{tabular}{|c|c|c|}
\hline$I$ & $D \leqslant 100 \mathrm{~km}$ & $D \leqslant 50 \mathrm{~km}$ \\
\hline $0.5-0.9$ & 19 & 19 \\
$1.0-1.4$ & 477 & 477 \\
$1.5-1.9$ & 210 & 209 \\
$2.15-2.4$ & 303 & 124 \\
$2.5-2.9$ & 252 & 43 \\
$3.0-3.4$ & 100 & 15 \\
$3.5-3.9$ & 34 & 5 \\
$4.0-4.4$ & 5 & - \\
$4.5-4.9$ & 2 & - \\
$5.0-5.4$ & 1 & 5 \\
\hline
\end{tabular}

Disuarding the sleoks with $I I<1$. 5 for $A \leqslant 100 \mathrm{~km}$ and with $I I<$ 1. 0 for $A \leqslant 50 \mathrm{~km}$ wo buvo, respostively:

$\begin{array}{lllllllll}M & 11 / 2 & 2 & 21 / 2 & 3 & 31 / 2 & 4 & 4^{1 / 2} & 5 \\ N_{1} & 913 & 703 & 100 & 1.18 & 42 & 8 & 3 & 1 \\ N_{1} & 228.25 & 175.75 & 100 & 37 & 10.50 & 2 & 0.75 & 0.25 \\ \log N_{1} & 2.36 & 2.21 & 2.00 & 1.57 & 1.02 & 0.30 & \ldots-10.12 & -0.60\end{array}$




$\begin{array}{lccccccc}M & 1 & 11 / 2 & 2 & 21 / 2 & 3 & 31 / 2 & 4 \\ Y_{1} & 874 & 397 & 188 & 64 & 21 & 6 & 1 \\ N_{1} & 218.50 & 99.25 & 47 & 16 & 5.25 & 1.5 & 0.25 \\ \log N_{1} & 2.34 & 1.99 & 1.67 & 1.20 & 0.72 & 0.17 & -0.60\end{array}$

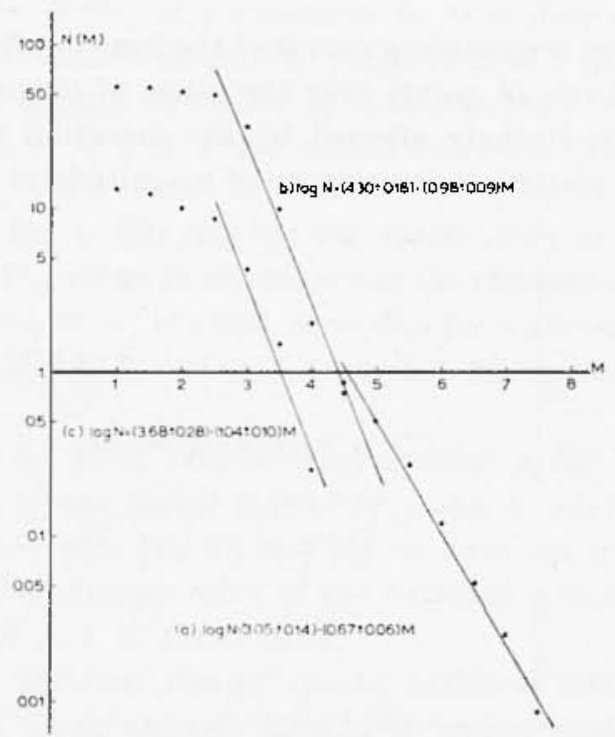

Fig. 4 -.. Cumulative frequency versus magnitude for the earthıuakes located in the major region of Attica over the poriod: (ii) $1850-1969$; (11) 1965 $1969 ;(c)$ in the minor region of Attica 1965-1969.

The alowe valuex orrespond, respertively, to

$$
\log N_{1} \cdots(3.99 \pm 0.21)-(0.89 \pm(0.11) \mathrm{H} I
$$

ithd

$$
\log N_{1}=(3.38 \pm 0.21)-(0.93 \div 0.11) \mathrm{H} .
$$

Tlum, by adding the shocks missed from the recordings of the Food-Anderson instruments, the minimum thresliold of the $N(M)$ relation is lowered by another half wnit. There is no rhange of $\mathrm{H}$ lor $N-1$, and the elabuge of $b$ is vory small. Discauling the showeks with,$I<2$ for $A \leqslant 100 \mathrm{~km}$, as well as for $1 \leqslant \mathrm{j} 0 \mathrm{~km}$, we get, respertively:

and

$$
\log N_{1}=(-4.42 \pm(1.24) \rightarrow(1.00+0.11) \mathrm{H}
$$

$$
\log N_{1}-(3.82 \pm 0.21)-(1.0 H \pm 0.11) \mu .
$$


Now there is a little cliange in the slopes, and for $A \leqslant 100 \mathrm{~km}$ the $M$ for $N_{1}=1$ romains almost the sames.

\section{I)ISOLSSTOX.}

Straiglat lines representing auves of the form $\log S^{\prime}=a-b M$ were fitterl to several sets of points over the range of magnitudes that peared not to be strongly afterter by the detection tluresliold. The rata have been plotteri in incerements of magnitures of 0.5 .

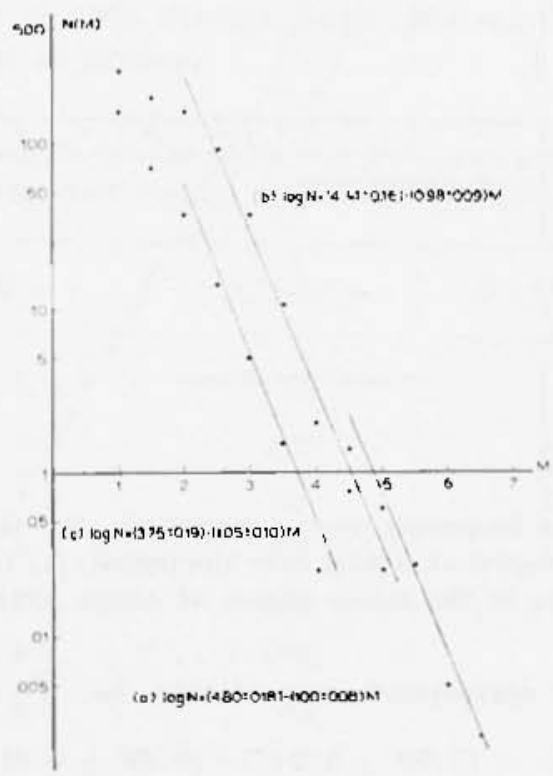

Fig. 5 - Cumulative frequency versus magnitule: (a) for the earthuluakes located in the major region of Altiea over the period 1930-1969; (h) for all locul shocks recoriled lig the standard Wool-Anderson instruments o $\mathrm{W}=$ 2890) within a tistance of $100 \mathrm{~km}$ irom Athens; and (c) willina distance of $50 \mathrm{~km}$.

The rurve for a 40-year perior (1930-1969) and a magniturie range of $1^{1 / 2}$ to $61 / 2$ has a slope of 1.0 . The same slopes shows the eurve for a 4-vear period (1965-1969) and a magnitude langse of 2 to 5 (sce Fig. 5). The two curvas diffor only in the constant $a$. Thes vibriance in the ronstant $n(4.80-4.34=0.46)$ indieates that the seismiaty derived from a sample of a slort period of obsorvation, 
inadorpate at the largest mannitudes, may be about 3 times smaller than that we get from a sample complete over all shocks recorded in a lone period of observation.

The corve for a 120-year period (1550-1969) and at magnitude lthere of fr/2 to $71 / 2$ has a siope of 0.67 (see Fig. 4). Tle constant a is very small (- 3.05$)$, in comparison to that derived for a t-year period (1965-1969) and a magnitude muge of 2 to $5(a-4.34)$. The two curves show strong difference in botl colntants a and $b$, but the $M$ for $N=1$ is 4.57 and 4.42 , respectively, i.e. witlin tle limits of error of $M$.

The onrve for at 120-year period (1850-1969) and a mannitude lange of $5 \frac{1}{2}$ to $7 \%$, ditlers in the slope and the constant a of the sturaight line litted between $M=4^{1 / 2}$ and $I I=61 / 2$ for a 40 -year period (19301969), but the $M$ for $A=1$ is 4.75 and 4.80 , respectively, i.e. virtamlly equal.

The curves for thee sets of shorks witlin a distance of $100 \mathrm{~km}$ of Atlens for a t-year period (1965-1969) and a minimum thesilobl $21 / 2,2$ and $11 / 2$ - eqs. [4], [5] and [9] - have an merage slope of $0.95-10.06$. The average value of the coustant $a$ is $4.21+0.22$, and thint of $M$ for $N=1$ is $4.42 \pm 0.06$.

The curves for four sets of sleocles within a distance of $50 \mathrm{~km}$ of Atlets for a 4 -year jeriod (1965-1969) and a minimm theshohd $21 / 2,2,1^{1 / 2}$ and $1-e^{2}[s .[6],[7],[8]$ and $[10]-$ have tan taverage slope of $0.99 \pm 0 .(06$. The average value of the coustatit a is $3.58 \pm 0.20$, and that of $Y$ for $N=1$ is $3.57+0.07$.

The kouttering of the alsolute valne of $b$ and of tle "once per yet." earthqualie $M$ in the major and minor regron of Attica is relatively small and of the same order of magnitude. The seattering of the constant $a$ is about thres times larger. This indicates that the "once per year" earthqualie $I I$ is a more reliable measure of seismicity tham the coustant a.

fomparing the average value of the constant a for the major und minor region of Attica $(4.21-3.58=0.633)$, we could surmise that the seismicity of tle major regrion is about four times greater thas that of the mitur region. Since the area of the major regrion is forr times larger than that of the minor region, the etathonale artivity per surface unit is nearly the same, i.e. virtually mulorm over the whole area. The active ath thatie fore in the minor region daring the period $1965-1969$ amonut to 26 . Tho active earthquale fori in the whole area total 103 . 


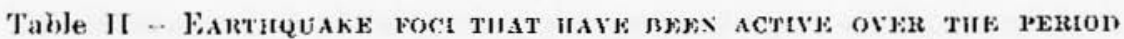
1805 to 1969 wITHIX a DIsTAKCE oF 106 KN FROM ATHENS.

\begin{tabular}{|c|c|c|c|c|c|}
\hline No & Dato & Toration & $\begin{array}{l}\text { Focal } \\
\text { Jepth } \\
\text { kin }\end{array}$ & $\begin{array}{l}\text { Magni. } \\
\text { tude } \\
\text { Adopterl }\end{array}$ & $\begin{array}{l}\text { Magni- } \\
\text { tude } \\
\text { Cumula. } \\
\text { tive }\end{array}$ \\
\hline 1 & 1968, April 25 & $38.0^{\circ} \mathrm{K}, 22.6 \mathrm{k} \mathrm{l}$ & 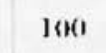 & $4^{1 / 2}$ & \\
\hline 2 & 1962, Bet. 4 & $38.1 \circ \mathrm{N}, 22.6 \circ \mathrm{c}$ & " & $5^{1 / 2}$ & \\
\hline 3 & 1879, July 3 & $38.2 \circ \mathrm{N}, 22.6$ 口 $\mathrm{E}$ & " & 5 & \\
\hline 4 & $\begin{array}{l}\text { 1953, June } 13 \\
1966, \text { Sopt. } 1 \\
1967, \text { June } 12\end{array}$ & $38.2 \circ, 22.7 \circ \mathrm{F}$ & $\begin{array}{l}\mathrm{H} \\
\mathrm{n} \\
\mathrm{n}\end{array}$ & $\begin{array}{l}5^{1 / 2} \\
4^{3} / 4 \\
4^{1} / 2\end{array}$ & $5 \%$ \\
\hline 5 & $\begin{array}{l}\text { 187t;, Jume } 26 \\
\text { 1929, Marrh } 3\end{array}$ & $37^{3} /,{ }^{0} \mathrm{~N}, 22^{3} /, \circ \mathrm{K}$ & $\begin{array}{l}n \\
\text { n }\end{array}$ & $\begin{array}{l}61 / 4 \\
51 / 4\end{array}$ & $0^{1} / 4$ \\
\hline 6 & $\begin{array}{l}\text { 1877, July } \\
\text { 1962, Jan. } 7\end{array}$ & $38.10 \mathrm{o}, 22^{3} / 4^{\circ} \mathrm{DE}$ & $\begin{array}{l}11 \\
11\end{array}$ & $\begin{array}{l}5^{1 / 2} / 2 \\
4^{3} / 5\end{array}$ & $5^{1 / 2} / 2$ \\
\hline 7 & $\begin{array}{l}\text { 1887, Oet. } 3 \\
1894 \text {, Narcl } 26 \\
\text { 1926. July } 2\end{array}$ & $38^{1} / 4 \circ \mathrm{o}, 22^{3} / 4 \mathrm{ol}$ & $\begin{array}{l}n \\
n \\
n\end{array}$ & $\begin{array}{l}61 / 4 \\
4^{3 / 4} \\
4^{3} / 4\end{array}$ & $\mathrm{fi}^{1} / \mathrm{s}$ \\
\hline 8 & 1967 , June 12 & 38.2 口N, $22.8 \circ \mathrm{k}$ & n & $4^{3} / 4$ & \\
\hline 9 & 1966, May 21 & $37.7 \circ \mathrm{N}, 22.9 \circ \mathrm{F}$ & 117 & $4^{1 / 2}$ & \\
\hline 10 & 1954, April 17 & $37.9 \circ \mathrm{N}, 22.9 \circ \mathrm{F}$ & n & $\pi^{1} i_{2}$ & \\
\hline 11 & $\begin{array}{l}\text { 1888, April J } \\
1898, \text { Aug. } 5\end{array}$ & $37^{1} .5 \circ \mathrm{N}, 23.0 \circ \mathrm{E}$ & " & $\begin{array}{l}4^{3} / 4 \\
5\end{array}$ & \\
\hline & $\begin{array}{l}\text { 1922, Aug. :5 } \\
\text { Nov. 11 } \\
\text { 1924, Febr. } 16\end{array}$ & $37.5 \circ \mathrm{K}, 23.1^{\circ} \mathrm{E}$ & $\begin{array}{c}\text { n } \\
\mathrm{i} \\
\mathrm{n}\end{array}$ & $\begin{array}{l}5 \\
53 \% \\
51 \%\end{array}$ & 6 \\
\hline 12 & 1962, Aug. 28 & $37.7 \circ, 23.0 \circ \mathrm{K}$ & 120 & $\mathrm{i}^{3} / \mathrm{i}$ & \\
\hline 13 & 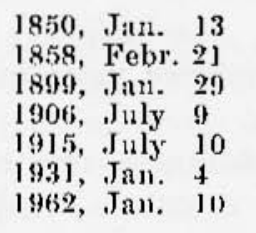 & $38.10 \circ \mathrm{X}, 23.110 \mathrm{~J}$ & $\begin{array}{l}\mathbf{n} \\
11 \\
n \\
n \\
n \\
n \\
n\end{array}$ & $\begin{array}{l}4^{3} / 4 \\
71 / 2 \\
4^{3} / 4 \\
4^{3} / 4 \\
43 \\
51 / 4 \\
4^{3} \% \\
4\end{array}$ & \\
\hline & $\begin{aligned} \text { 3928, April } 22 \\
\text { April } 22 \\
\text { April } 24 \\
\text { April } 25 \\
\text { June } 7 \\
\text { I953, Sept. } 5\end{aligned}$ & $38.0 \mathrm{~N} \mathrm{~N}, 23.0 \mathrm{o} \mathrm{s}$ & $\begin{array}{l}n \\
n \\
n \\
n \\
n \\
n\end{array}$ & $\begin{array}{l}5^{-1} / 4 \\
6^{3} / 4 \\
5 \\
5^{1} / 4 \\
5 \\
5^{3} ; 4\end{array}$ & $7 \%$ \\
\hline 14 & 1941, July 29 & $38^{1} / 4 \mathrm{~N}, 23.0 \circ \mathrm{E}$ & $n$ & $\pi$ & \\
\hline 15 & 1961, Jyec. 13 & $38.5 \circ \mathrm{N}, 23.0 \circ \mathrm{ol}$ & II & $+1 / 2$ & \\
\hline
\end{tabular}


Tahle 11 (cont.)

\begin{tabular}{|c|c|c|c|c|c|}
\hline No & Date & Ioreationt & $\begin{array}{c}\text { Focal } \\
\text { [opptli } \\
\text { kn1 }\end{array}$ & $\begin{array}{l}\text { Magni- } \\
\text { Iuds } \\
\text { Salıptid }\end{array}$ & $\begin{array}{c}\text { Magni- } \\
\text { lude } \\
\text { Connulat } \\
\text { tise }\end{array}$ \\
\hline 16 & 1916, Sept. 27 & $38^{3} / 4 \circ \mathrm{N}, 23.0 \circ \mathrm{E}$ & $n$ & $5^{1} / 2$ & \\
\hline 17 & 19666, JaIt. 2 & $37 . \times \circ \mathrm{N}, 23.1 \circ \mathrm{k}$ & ॥ & $4^{3 / 4}$ & \\
\hline 18 & 1958, May 21 & $38.1 \circ \mathrm{N}, 23.1 \circ \mathrm{E}$ & n & $+^{1 / 2}$ & \\
\hline 19 & 1894, April 27 & $38.7 \mathrm{oN}, 23.1 \mathrm{o}:$ & $\mathrm{n}$ & 7 & \\
\hline 20 & 1968, July + & $37.7 \circ \mathrm{N}, 23.2 \circ \mathrm{F}$ & $n$ & $5^{1} / 4$ & \\
\hline 21 & $1928 . A_{1}$ ril 29 & $38.11 \mathrm{or}, 23.2 \mathrm{\circ E}$ & $\mathrm{n}$ & $5^{1} i$ & \\
\hline 22 & $1894, A_{j}$ ril 20 & $38.6 \circ \mathrm{N}, 23.2 \circ \mathrm{W}$ & u & $6^{3} / 4$ & \\
\hline 23 & $\begin{array}{l}\text { 1947, April 19 } \\
1952, \text { Oet. } 13\end{array}$ & 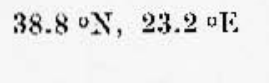 & " & $51 / 4$ & $5^{3 / 4}$ \\
\hline 24 & 1922, Ang. 8 & $37.5 \circ \mathrm{N}, 23^{1 / 4} \circ \mathrm{E}$ & "I & $51 \%$ & \\
\hline 25 & $\begin{array}{rr}\text { 1873, July } & 25 \\
1930, \text { April } 17 \\
\text { Sept. } 12 \\
\text { Sept. } 12 \\
\text { Sept. } 12 \\
\text { Sep1. } 15\end{array}$ & $37^{3} / 4^{\circ} \mathrm{N}, 23^{1} \%^{\circ}{ }^{\circ} \mathrm{E}$ & $\begin{array}{l}n \\
n \\
n \\
n \\
n \\
n\end{array}$ & $\begin{array}{l}61 / 4 \\
5^{3} / 4 \\
5^{1} / 4 \\
5^{1} / 4 \\
5 \\
5^{1} / 4\end{array}$ & $\mathbf{b}^{1 / 2}$ \\
\hline 26 & 1964, Jn15 12 & $38.5 \circ \mathrm{\circ}, 23^{1} / \mathrm{s}$ & " & $4^{3 / 4}$ & \\
\hline 27 & 1961, Mata 19 & $38^{3} / 4^{\circ}, 23^{1}{ }_{i+}$ oE & n & $4^{1 / 2}$ & \\
\hline 28 & 196s, Julte 17 & $37.8 \circ \mathrm{N}, 23.3 \circ \mathrm{E}$ & 150 & $4^{1} \cdot{ }_{2}^{\prime}$ & \\
\hline 29 & 1952, Sejt. 12 & $38.4 \mathrm{or}, 23.40 \mathrm{E}$ & n & $4^{1 / 2}$ & \\
\hline 30 & 1837, Hareh $20^{*}$ & 37.5 吹, 23.5 吃 & $n$ & 6 & \\
\hline 31 & $\begin{array}{l}\text { 1893, Nov. } 14 \\
1926 \text {, Oet. } 30\end{array}$ & $38.0 \circ \mathrm{N}, 23.5 \circ \mathrm{k}$ & $\begin{array}{l}\mathrm{n} \\
\mathrm{n}\end{array}$ & $\begin{array}{l}4^{3} / 4 \\
4^{3} \%\end{array}$ & \\
\hline 32 & $\begin{array}{l}\text { 1853, Aur. I8 } \\
1893 \text {. Nay } 23 \\
\text { 1914, Oct. } 17 \\
\text { Oct. } 17 \\
\text { Dec. } 2 \\
\text { 1917, Sept. } 23 \\
\text { 1962, Oet. 65 }\end{array}$ & $38^{1 / 4} \circ \mathrm{N}, 23.5 \circ \mathrm{E}$ & $\begin{array}{l}n \\
n \\
11 \\
n \\
n \\
n \\
n\end{array}$ & $\begin{array}{l}7^{1 / 4} \\
6 \\
6 \\
6 \\
51 / 2 \\
51 / 2 \\
4^{1} / 2\end{array}$ & $7^{1}: 2$ \\
\hline 33 & $\begin{array}{l}\text { 1864, July } 17 \\
1867, \text { Jan. } 2 \\
1868, \text { Jee. } 28 \\
1874 \text {, Marel, is } \\
1902 \text {, Ajril 11 } \\
\text { May 1 }\end{array}$ & $38.5 \circ \mathrm{N}, \quad 23.5 \circ \mathrm{E}$ & $\begin{array}{l}n \\
n \\
n \\
n \\
n \\
n\end{array}$ & $\begin{array}{l}5^{1} / 2 \\
5^{1} / 2 \\
4^{3} / 4 \\
51 / 4 \\
4^{1} / 4 \\
4^{3} / 4\end{array}$ & $151: 4$ \\
\hline 34 & 1885, Aug. 22 & $38 \% / 4 \circ, \quad 23 \mathrm{aF} .3$ & "I & $52 / 4$ & \\
\hline
\end{tabular}

NOTE: Asterist denoles block not used in statistien (eee $\mathrm{N}^{\circ} 3(1-19)$ ). 
Table II (esint.)

\begin{tabular}{|c|c|c|c|c|c|}
\hline $\mathrm{Nu}^{u}$ & Date & laxpation & $\begin{array}{l}\text { Focal } \\
\text { Jepth } \\
\text { lim }\end{array}$ & $\begin{array}{l}\text { Magni. } \\
\text { tukle } \\
\text { tibipted }\end{array}$ & $\begin{array}{c}\text { Magni- } \\
\text { imile } \\
\text { Cumula. } \\
\text { live }\end{array}$ \\
\hline & 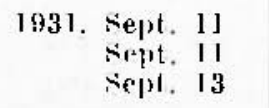 & $3 \mathrm{~N}:{ }^{\circ} \mathrm{N}, 23.5 \mathrm{\circ E}$ & $\begin{array}{l}11 \\
11 \\
11\end{array}$ & $\begin{array}{ll}51 & \\
5 & 4 \\
51 & 4 \\
5 & 1\end{array}$ & 1. \\
\hline 35 & 1964, .July 17 & $38.05 \circ \mathrm{\circ}, 23.0 \mathrm{\circ} \mathrm{E}$ & 155 & (3) & \\
\hline 36 & $196 \mathrm{~J}, \mathrm{sep} 1 . \overline{5}$ & $38.6 \circ \mathrm{N}, 23.6 \mathrm{\circ} \mathrm{E}$ & n & $4^{3 / 1}$ & \\
\hline 37 & 3957 , May 29 & 37.1 ० $\mathrm{K} .23 .7 \mathrm{\circ K}$ & n & $5^{1 / 2}$ & \\
\hline 38 & ]9fit. Sept. 29 & $38.90 \mathrm{~N}, 23.7 \mathrm{\circ}$ & 89 & $+1 / 2$ & \\
\hline $3 ! !$ & $\begin{array}{lll}\text { l874, Jan. } & 17 \\
\text { ]889, Jaul. } & 22 \\
1934, \text { Janl. } & 2 \\
1938, \text { July } & 20 \\
& \text { July } & 27 \\
1957, \text { Jec. } & 13\end{array}$ & $38^{1 / 1} \circ, 23^{3 / 1} \circ \mathrm{N}$ & $\begin{array}{l}n 1 \\
11 \\
11 \\
11 \\
n \\
n\end{array}$ & $\begin{array}{l:l}51 & 1 \\
4^{3} & 1 \\
4^{3} & 1 \\
5 & 1 \\
5 & 1 \\
4^{1} & 2\end{array}$ & $61 / 1$ \\
\hline 40 & 1962, Jant 4 & $38.5 \circ \mathrm{N}, \quad 23^{3}: 10 \mathrm{~K}$ & " & $4^{1} ; 2$ & \\
\hline+1 & $1957, A$ Ar. 2 & $38^{3} /, x, 23^{3} / 4^{\circ}$ & n & $4^{1}: 2$ & \\
\hline 42 & I959, Mareb 13 & $37.3 \circ \mathrm{X} .23 .8$ 听 & "I & $4 \%$ & \\
\hline 43 & 19ijli, Yiareli 27 & $37.9 \cup \mathrm{N}, 23.80 \mathrm{~L}$ & 179 & $4^{1}: 2$ & \\
\hline 44 & 1956 , April 13 & $\left.38.2 \mathrm{oN}, 23.8^{\circ}\right]$ & $\mathrm{n}$ & $4^{1 / 2}$ & \\
\hline 45 & 1955, Febr. 9 & $38.3 \mathrm{oN}, 23.9 \mathrm{ol}$ & n & $4^{1}: 2$ & \\
\hline 46 & $1919,0 \mathrm{et} .13$ & $38.4^{\circ} \mathrm{N}, 23.9 \mathrm{og}$ & n1 & 5 & \\
\hline 47 & 1961, Mard 6 & $38^{\circ} 27^{\prime} \mathrm{N}, 23^{\circ} 57^{\prime} \mathrm{K}$ & 11 & $4: 2$ & \\
\hline 48 & I95t, Jan. I3 & $37.1 ; \circ \mathrm{N}, 24.0 \circ \mathrm{og}$ & n & $5 i_{i 1}$ & \\
\hline $4 !$ & 1805, Nov. 115/17* & $38 .(1 \circ \mathrm{N}, 24.0 \circ \mathrm{E}$ & n & $55^{1 / 2}$ & \\
\hline 5) & 1958 . June 10 & $38.4 \circ \mathrm{N}, 24.11 \circ \mathrm{E}$ & II & $4^{1 / 2}$ & \\
\hline 51 & $\begin{array}{l}\text { 1964, Oct. } 27 \\
1968 \text {. April । }\end{array}$ & $\begin{array}{l}38.5 \circ \mathrm{N}, 24.0 \mathrm{O} \\
38.5 \circ \mathrm{N}, 24.0 \circ \mathrm{W}\end{array}$ & $\begin{array}{l}\text { n } \\
\text { I1 }\end{array}$ & $\begin{array}{l}4^{1 / 1} / 2 \\
4^{1 / / 2}\end{array}$ & 5 \\
\hline 52 & 1900, Jitnl. 12 & $38^{3} /, 0 \mathrm{~N}, 24.11+\mathrm{k}$ & 11 & $4^{3 / 1}$ & \\
\hline 53 & $196 \mathrm{i} 7$, A un. 28 & $38.3 \circ \mathrm{N}, 24.1 \circ \mathrm{K}$ & n & $41 / 2$ & \\
\hline 54 & $1915 \overline{5}$, Matrel 9 & $38.8 \circ \mathrm{N}, 24.1 \mathrm{kl}$ & $4 \overline{1}$ & $4^{1 / 2}$ & \\
\hline 55 & I891, M:1,y ll & $37.5 \circ \mathrm{N}, 2+1,0 \mathrm{k}$ & $n$ & is & \\
\hline 56 & 1950, Jan. 18 & $37^{3} / 1, N, 2+1 / 4, \mathrm{k}$ & Il & $5^{1}$ & \\
\hline 57 & 1968, April 17 & 38.7 oN. 24.4 ol: & $\mathrm{n}$ & $+1 / 2$ & \\
\hline 58 & 1918, Jan. 17 & $37^{1} / 1^{\circ} \mathrm{N}, 24.5 \circ \mathrm{N}$ & n & $51 / 2$ & \\
\hline 59 & 1883, Ang. . & $37.5 \circ \mathrm{N}, 24.5 \circ \mathrm{l}$ & 11 & $4^{3 / 1}$ & \\
\hline
\end{tabular}




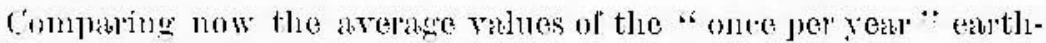
quilie $Y$ for the major and minor recrion of Attion (4.42-3.5i 0.85), we rould draw the comelusion that the stismicity of the major region is about $f$ times greter than that of the minor regiun, i.e. the cartigualse activity per sulface anit in the outer region is two times higler than that in the inner region. The conclusion holds for shocks with $H \geqslant 21 \%$, i.ts. lor sampling equally eomplete for both regrions: it is, therefore, mus lowe close to the trutll. The data points that establish the enues for the major and minur region of Attica (s. Hig. b) remain on the line down to $M=1.5$ and $M=1.0$, respertively. This means that the lower bending of the anves is ronditioned by the detertion thesesold. The ditherence in the detection thresholil for the major and minor region dues not alfert the comparison of the individual levels of seismicity.

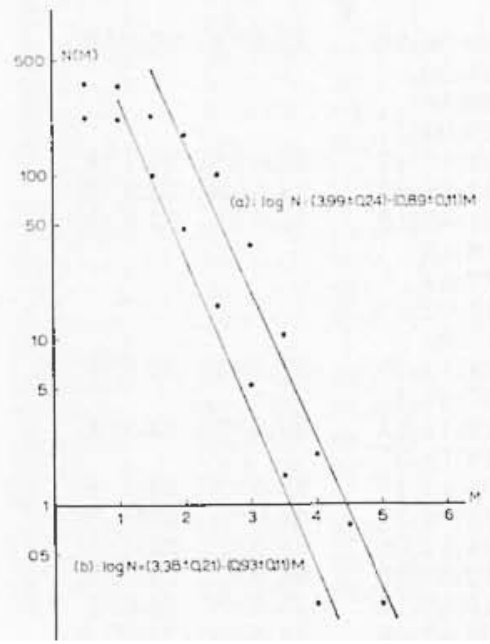

Tig. 6 - Cummlative frefueney versux magnitude for all focal slinclis reenrterd by the Beniofi vertical instrument $(V=32.500)$; (a) wiihin a distathe of $100 \mathrm{~km}$ from Athons; (li) within a tistante of $50 \mathrm{~km}$.

The mper bending of the alues is ronditioned hy the periond of observation, i.e. is time dependent. mue miximm mibnitule ob-

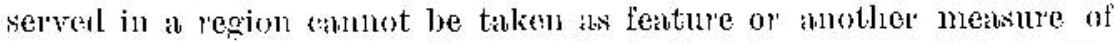

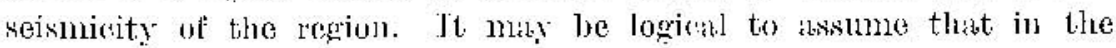

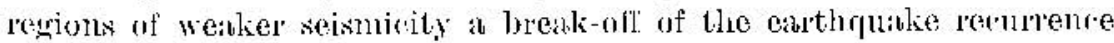

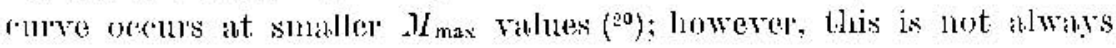




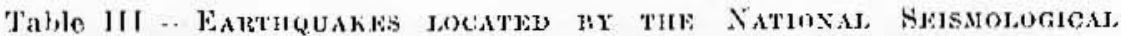

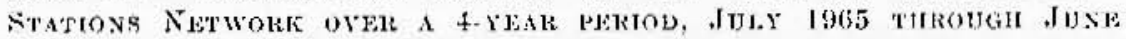

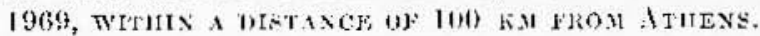

\begin{tabular}{|c|c|c|c|c|}
\hline 1)ate & Origin & Location & $\begin{array}{c}\text { Distance } \\
\mathrm{kmm}\end{array}$ & Iagnitude \\
\hline  & $\begin{array}{l}13: 54: 28 \\
16: 02: 22 \\
11: 38 \\
02: 47 \\
09: 41 \\
18: 29: 03 \\
23: 01: 09 \\
2(1: 25: 08 \\
14: 53: 58 \\
04: 08: 40 \\
11: 19: 51 \\
01: 09: 54\end{array}$ & 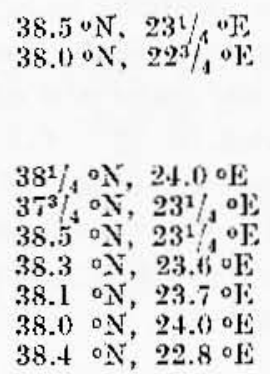 & $\begin{array}{l}70 \\
85 \\
15 \\
90 \\
50 \\
60 \\
55 \\
70 \\
35 \\
15 \\
25 \\
85\end{array}$ & $\begin{array}{l}3.3 \\
3.9 \\
3.1 \\
3.0 \\
2.6 \\
2.6 \\
3.3 \\
3.3 \\
2.9 \\
2.9 \\
2.7 \\
3.5\end{array}$ \\
\hline  & $\begin{array}{l}20: 56: 36 \\
21: 30 \\
22: 19 \\
23: 03 \\
23: 12: 17 \\
13: 32: 27 \\
01: 49: 12 \\
13: 45 \\
13: 58 \\
15: 02 \\
15: 08 \\
22: 14: 25 \\
07: 51: 41 \\
18: 1+: 54 \\
18: 18: 37 \\
01: 41: 47 \\
18: 02: 17 \\
04: 11: 08 \\
12: 35: 29 \\
13: 10: 13 \\
06: 47: 48 \\
09: 48: 40 \\
21: 21: 33 \\
00: 23: 06 \\
00: 54: 58 \\
22: 11: 15 \\
22: 32: 28 \\
21: 14: 08 \\
01: 11: 26 \\
05: 47 \\
00: 51 \\
23: 41029 \\
09: 52: 12 \\
20: 29: 42 \\
20: 08: 17\end{array}$ & 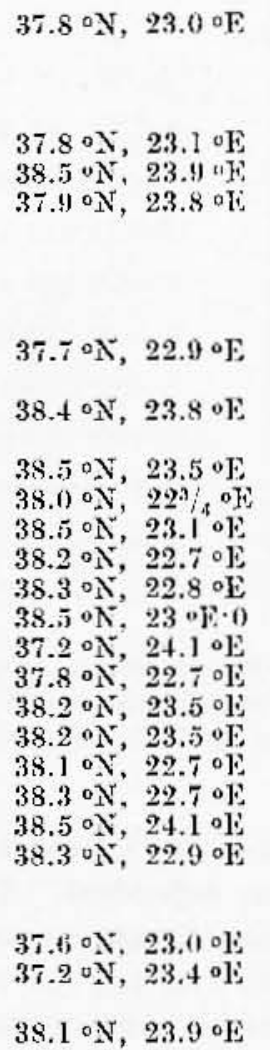 & $\begin{array}{c}65 \\
65 \\
(65) \\
60 \\
65 \\
70 \\
15 \\
20 \\
20 \\
10 \\
10 \\
80 \\
20 \\
45 \\
25 \\
60 \\
90 \\
60 \\
90 \\
90 \\
93 \\
95 \\
95 \\
35 \\
35 \\
95 \\
95 \\
70 \\
80 \\
10 \\
15 \\
100 \\
100 \\
90 \\
20\end{array}$ & $\begin{array}{l}3.9 \\
2.4 \\
2.5 \\
2.5 \\
4.7 \\
3.4 \\
3.8 \\
1.4 \\
1.4 \\
1.1 \\
1.3 \\
3.4 \\
2.5 \\
3.3 \\
1.8 \\
3.0 \\
3.1 \\
3.0 \\
3.4 \\
3.1 \\
3.1 \\
2.9 \\
2.8 \\
3.5 \\
3.0 \\
3.3 \\
3.8 \\
2.7 \\
3.0 \\
1.6 \\
1.6 \\
2.8 \\
2.9 \\
2.9 \\
2.4\end{array}$ \\
\hline
\end{tabular}


'Jable [II (cont.)

\begin{tabular}{|c|c|c|c|c|c|c|}
\hline \multicolumn{3}{|c|}{ Tate } & Origin & Irocations & $\begin{array}{l}\text { 1)istamce } \\
\text { kiul }\end{array}$ & $\operatorname{Mannilude}_{M_{L}}$ \\
\hline 1967, & 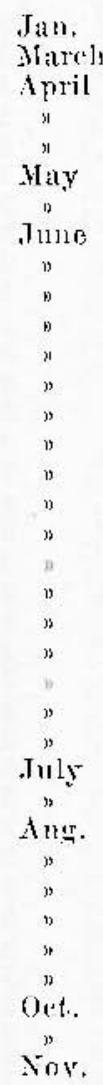 & $\begin{array}{r}10 \\
130 \\
8 \\
10 \\
12 \\
26 \\
26 \\
7 \\
8 \\
8 \\
8 \\
8 \\
11 \\
11 \\
11 \\
11 \\
11 \\
12 \\
12 \\
12 \\
12 \\
15 \\
15 \\
16 \\
18 \\
3 \\
27 \\
23 \\
25 \\
28 \\
28 \\
28 \\
28 \\
10 \\
26 \\
3\end{array}$ & $\begin{array}{l}10: 35: 24 \\
09: 53: 35 \\
13: 10 \\
14: 20 \\
23: 12: 23 \\
13: 15: 38 \\
13: 22 \\
07: 53: 31 \\
00: 03: 16 \\
00: 25 \div 35 \\
13: 07: 27 \\
19: 58: 13 \\
05: 35 ; 01 \\
10: 001: 19 \\
10: 04: 16 \\
13: 31: 15 \\
22: 50: 14 \\
01: 29: 05 \\
02: 51: 02 \\
11: 011: 14 \\
22: 51: 34 \\
13: 23: 37 \\
19: 34: 06 \\
17: 46: 30 \\
23: 37: 14 \\
13: 17: 13 \\
15: 57: 50 \\
00: 05: 28 \\
13: 15: 08 \\
02: 33: 49 \\
03: 39: 03 \\
03: 43: 12 \\
03: 51 \\
17: 32: 27 \\
05: 35: 28 \\
019: 46: 01\end{array}$ & 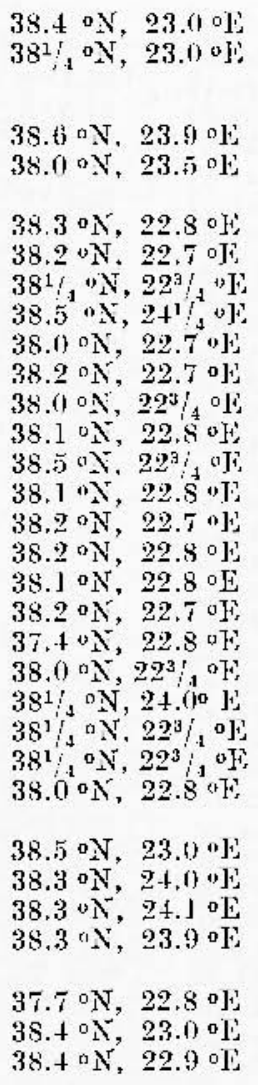 & $\begin{array}{c}80 \\
60 \\
10 \\
10 \\
70 \\
15 \\
10 \\
90 \\
100 \\
100 \\
60 \\
85 \\
95 \\
100 \\
85 \\
95 \\
90 \\
90 \\
90 \\
85 \\
95 \\
100 \\
(85) \\
40 \\
100 \\
95 \\
80 \\
55 \\
85 \\
50 \\
55 \\
40 \\
45 \\
90 \\
80 \\
80\end{array}$ & $\begin{array}{l}3.0 \\
3.0 \\
1.7 \\
1.5 \\
3.9 \\
1.7 \\
1.5 \\
3.7 \\
3.7 \\
2.7 \\
3.1 \\
2.9 \\
3.8 \\
2.9 \\
3.2 \\
3.1 \\
3.3 \\
4.0 \\
4.4 \\
2.4 \\
3.4 \\
2.9 \\
2.8 \\
2.15 \\
2.7 \\
2.4 \\
2.8 \\
2.9 \\
3.1 \\
2.6 \\
3.7 \\
2.5 \\
2.0 \\
2.7 \\
2.9 \\
2.8\end{array}$ \\
\hline 1968, & 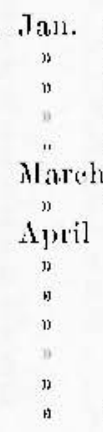 & $\begin{array}{r}16 \\
17 \\
17 \\
21 \\
28 \\
125 \\
30 \\
1 \\
6 \\
6 \\
16 \\
7 \\
7 \\
13\end{array}$ & $\begin{array}{l}08: 32: 59 \\
21: 01: 40 \\
23: 22: 05 \\
13: 58: 38 \\
22: 49: 18 \\
15: 31: 26 \\
11: 50: 04 \\
06: 27: 22 \\
12: 26: 46 \\
19: 26: 48 \\
23: 34: 26 \\
03: 41: 55 \\
03:-5: 12 \\
1+:-8: 54\end{array}$ & 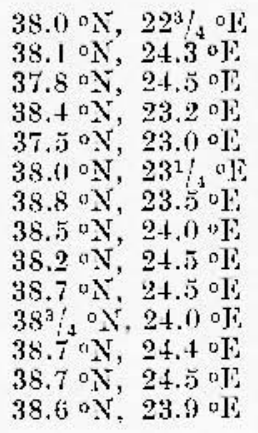 & $\begin{array}{r}75 \\
55 \\
55 \\
70 \\
85 \\
25 \\
160 \\
65 \\
95 \\
1610 \\
100 \\
160 \\
100 \\
65\end{array}$ & $\begin{array}{l}2.9 \\
3.1 \\
2.8 \\
3.7 \\
2.8 \\
2.5 \\
3.3 \\
4.4 \\
3.5 \\
3.3 \\
3.0 \\
4.2 \\
3.5 \\
3.3\end{array}$ \\
\hline
\end{tabular}


Table Ill (couti)

\begin{tabular}{|c|c|c|c|c|c|c|}
\hline & Jate & & Origgin & Joctation & $\begin{array}{c}\text { J) isilatece } \\
\text { knll }\end{array}$ & Magnitude \\
\hline 列 & 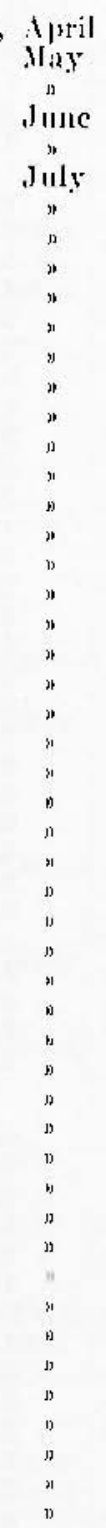 & $\begin{array}{r}25 \\
4 \\
19 \\
11 \\
17 \\
4 \\
4 \\
4 \\
4 \\
4 \\
5 \\
5 \\
5 \\
5 \\
5 \\
5 \\
5 \\
5 \\
5 \\
5 \\
5 \\
5 \\
5 \\
6 \\
6 \\
6 \\
6 \\
6 \\
6 \\
6 \\
6 \\
6 \\
7 \\
7 \\
7 \\
7 \\
7 \\
7 \\
7 \\
8 \\
9 \\
9 \\
10 \\
10 \\
10 \\
10 \\
10 \\
11 \\
12 \\
13 \\
13\end{array}$ & $\begin{array}{l}10: 34: 1) 4 \\
09: 36: 54 \\
09: 18: 12 \\
13: 52: 04 \\
11: 16: 38 \\
21: 47: 51 \\
22:+2: 04 \\
23: 04: 30 \\
23: 28: 27 \\
23: 33: 23 \\
00: 37: 56 \\
02: 12: 30 \\
02: 26: 48 \\
04: 42:+6 \\
11: 44: 38 \\
14: 56: 57 \\
15: 08: 45 \\
15: 14: 56 \\
15: 19: 50 \\
17: 49: 23 \\
20: 12: 20 \\
21: 05: 15 \\
22: 25: 52 \\
01: 13: 48 \\
05: 24: 44 \\
08: 02: 51 \\
16: 25: 54 \\
17: 30: 51 \\
19: 45: 43 \\
21: 55: 32 \\
22: 20: 25 \\
22: 43: 23 \\
00: 51: 16 \\
01: 27: 05 \\
05: 44: 07 \\
08: 14: 27 \\
10: 13: 29 \\
16: 08: 10 \\
22: 29: 17 \\
07: 15: 13 \\
1+: 32: 50 \\
16: 49: 59 \\
03: 48: 04 \\
05: 32: 05 \\
16: 22: 13 \\
21: 36: 29 \\
23: 29: 34 \\
05: 50: 20 \\
110: 21: 00 \\
1+: 50 ; 16 \\
17: 31: 02\end{array}$ & 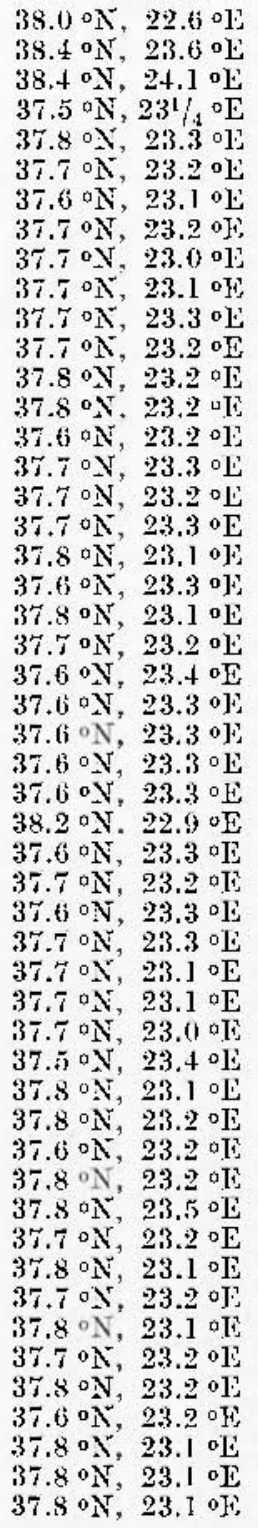 & $\begin{array}{l}90 \\
50 \\
65 \\
80 \\
50 \\
60 \\
45 \\
60 \\
65 \\
60 \\
60 \\
60 \\
55 \\
60 \\
65 \\
60 \\
65 \\
60 \\
60 \\
60 \\
60 \\
55 \\
55 \\
60 \\
60 \\
60 \\
60 \\
85 \\
60 \\
60 \\
60 \\
60 \\
60 \\
60 \\
65 \\
60 \\
60 \\
50 \\
65 \\
60 \\
60 \\
60 \\
60 \\
50 \\
60 \\
60 \\
55 \\
65 \\
60 \\
55 \\
60\end{array}$ & $\begin{array}{l}3.9 \\
3.0 \\
3.2 \\
2.6 \\
3.5 \\
5.0 \\
3.1 \\
3.2 \\
3.0 \\
3.0 \\
2.0 \\
3.1 \\
2.8 \\
3.2 \\
3.0 \\
3.1 \\
3.5 \\
3.3 \\
3.0 \\
3.3 \\
3.1 \\
3.1 \\
3.2 \\
2.9 \\
2.4 \\
3.2 \\
3.5 \\
3.4 \\
3.0 \\
3.8 \\
3.3 \\
3.2 \\
3.6 \\
3.0 \\
3.5 \\
2.8 \\
2.8 \\
2.8 \\
2.9 \\
3.0 \\
3.0 \\
3.0 \\
3.5 \\
3.0 \\
3.0 \\
3.4 \\
2.7 \\
2.7 \\
3.2 \\
2.6 \\
3.3\end{array}$ \\
\hline
\end{tabular}


Table JII (cont.)

\begin{tabular}{|c|c|c|c|c|c|c|}
\hline \multicolumn{3}{|c|}{ Diate } & Origin & Tocation & $\begin{array}{l}\text { Distance } \\
\text { lkm }\end{array}$ & $\operatorname{Mragnil}_{Y_{L}}$ \\
\hline \multirow[t]{49}{*}{ L96s, } & July & 13 & $19: 38: 20$ & $37.70 \mathrm{~N}, 23.3$ ol & 50 & 3.4 \\
\hline & & 14 & $16: 26: 51$ & $37.6 \circ \mathrm{N}, 23.3 \circ \mathrm{E}$ & 60 & 2.7 \\
\hline & & 14 & $18: 33: 52$ & $37.7 \circ \mathrm{N}, 23.2 \circ \mathrm{E}$ & 55 & 3.6 \\
\hline & & 16 & $(x): 54: 43$ & $38.7 \circ \mathrm{N}, 23.5 \circ \mathrm{L}$ & $(65$ & 3.0 \\
\hline & & 16 & $22: 43: 35$ & $37.6 \circ \mathrm{N}, 23.3 \circ \mathrm{d}$ & 60 & 2.9 \\
\hline & $"$ & 21 & $14: 40: 27$ & $38.5 \circ \mathrm{N}, 23.7 \circ \mathrm{L}$ & 60 & 2.9 \\
\hline & & 22 & $07: 48: 12$ & $37.6 \circ \mathrm{N}, 23.1$ OL & 50 & 3.9 \\
\hline & Allg. & 10 & $08: 44: 36$ & $37.8 \circ \mathrm{N}, 23.1 \circ \mathrm{E}$ & 60 & 3.4 \\
\hline & $n$ & $1 \overline{5}$ & (1) $1: 0 \overline{7}: 15$ & $38,+0 \mathrm{~N}, 24.0$ ㄴ. & 50 & 3.1 \\
\hline & $"$ & 22 & $22: 46: 28$ & 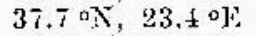 & 50 & 2.6 \\
\hline & " & 23 & $12: 21: 36$ & $37.7 \circ \mathrm{N}, 23.2 \mathrm{ol}$ & 65 & 2,6 \\
\hline & a & 2.1 & $18: 17: 34$ & $37.5 \circ \mathrm{O}, 23.4 \circ \mathrm{E}$ & 65 & 3.2 \\
\hline & a & 26 & $00 \div 24: 20$ & $37.7 \circ \mathrm{N}, 23.3 \circ \mathrm{b}$ & 601 & 2.9 \\
\hline & Sept. & 3 & $22 \div 59: 59$ & $37.7 \circ \mathrm{N}, 23.2$ ०E & 60 & 3,1 \\
\hline & p & y & $14: 44: 07$ & 37.8 ०N, 23.2 ol: & 5,5 & 2,6 \\
\hline & $n$ & 12 & $10: 36: 30$ & 37.8 ० $\mathrm{N}, 23.2 \circ \mathrm{og}$ & 60 & 3.5 \\
\hline & " & 18 & $07: 14: 11$ & $37.8 \mathrm{\circ}, 23.2 \mathrm{ot}$ & 60 & 2.9 \\
\hline & $n$ & 18 & $14: 18: 22$ & $38.4 \circ \mathrm{N}, \quad 23.6 \circ \mathrm{E}$ & 45 & 2.9 \\
\hline & $n$ & $1 \mathrm{~s}$ & $14: 27: 12$ & $38.3 \circ \mathrm{N}, 23.7 \circ \mathrm{E}$ & 40 & 3.3 \\
\hline & v & 19 & $15: 0 \$: 59$ & $37^{3 / 4}$ ○N, $23^{3} / 4$ oJ & 60 & 2.9 \\
\hline & " & 22 & $00: 55: 27$ & $37.5 \cup 5,23.10 \mathrm{E}$ & 60 & 2.9 \\
\hline & n & 23 & $14: 43: 43$ & $38.40 \mathrm{~N}, 23.5 \mathrm{ol}$ & 40 & 3.3 \\
\hline & oet. & 8 & $04: 11: 28$ & $37 . \bar{T} \mathrm{\circ}, 23.1 \mathrm{\circ}$ & 60 & 2.5 \\
\hline & w & 12 & $08: 53: 57$ & $38.8 \mathrm{\circ}, 23.9 \circ \mathrm{E}$ & 85 & 3.0 \\
\hline & $a$ & 14 & $01: 42: 30$ & $37.6 \mathrm{\circ} \circ, 23.3 \circ \mathrm{E}$ & 65 & 3.9 \\
\hline & n & 14 & $03: 02: 51$ & $37.4 \circ \mathrm{N}, 23.50 \mathrm{l}$ & 60 & 2.16 \\
\hline & $n$ & 14 & $03: 40: 18$ & 37.7 ०N, 23.3 ०E & 60 & 2.6 \\
\hline & $"$ & 14 & $07: 59: 21$ & $37.7 \circ \mathrm{N}, 23.3 \mathrm{\circ L}$ & 65 & 2.7 \\
\hline & $"$ & 14 & $08: 51: 50$ & $37.7 \mathrm{oN}, 23.4 \mathrm{oE}$ & (6) & 2.7 \\
\hline & x & 14 & $17: 08: 02$ & $37.9 \circ \mathrm{N}, 23.2 \circ \mathrm{O}$ & 50 & 3.3 \\
\hline & n & 17 & $03: 48: 59$ & $3 \mathrm{~s}^{1} /, \circ \mathrm{N}, 24,50 \mathrm{O}$ & 75 & 2.8 \\
\hline & 0 & 23 & $05: 17: 22$ & $37.7 \circ \mathrm{N}, 23.40 \mathrm{CH}$ & 55 & 3.0 \\
\hline & $\mathrm{n}$ & 23 & $12: 20: 17$ & 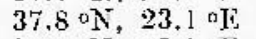 & 60 & 3.1 \\
\hline & w & 21 & $0 L: 26: 55$ & $37.60 \mathrm{~N}, 23.3 \circ \mathrm{OL}$ & b0 & 3.6 \\
\hline & " & 24 & $04: 34: 44$ & $38.1+\mathrm{N}, 24.0 \circ \mathrm{li}$ & 20 & 1.9 \\
\hline & $n$ & 26 & $02: 03: 14$ & $38^{3} / 1^{\circ N}, 23^{1} / 4$ of & 65 & 2.6 \\
\hline & n & 26 & $06: 24: 50$ & $37.6 \circ \mathrm{N}, 23.2 \mathrm{oJ}$ & 70 & 2.7 \\
\hline & "1) & 26 & $06: 27: 46$ & $37.1,0 \mathrm{~N}, 23.4 \mathrm{O}$ & bjoj & 3.1 \\
\hline & Nor. & 2 & $22: 58: 38$ & 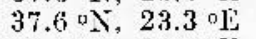 & (ij) & 3.0 \\
\hline & w & 11 & $04: 58: 51$ & 38.1 N, $24.3 \circ \mathrm{E}$ & $\breve{5} 5$ & 3.2 \\
\hline & $\mathrm{p}$ & 16 & $15: 38: 43$ & $38.0 \circ \mathrm{N}, 24.5$ ०L: & 60 & 3.3 \\
\hline & $n$ & 20 & $05: 17: 33$ & $37.6 \circ \mathrm{N}, 23.2$ o & 60 & 3.3 \\
\hline & $"$ & 20 & $19: 46: 50$ & $38.5 \circ \mathrm{X}, 23.4 \circ \mathrm{E}$ & 55 & 2.1 \\
\hline & $"$ & 22 & $01: 00: 13$ & $381,0 \mathrm{~N}, 24.5 \circ \mathrm{E}$ & 60 & 3.0 \\
\hline & Dee. & 10 & $20: 13: 23$ & $38.5 \circ \mathrm{N}, 23.0 \mathrm{\circ}$ & 85 & 3.3 \\
\hline & s & $\mathrm{J}(\mathrm{i}$ & $1: 5: 34: 37$ & $37.8 \circ \mathrm{N}, 23.7 \mathrm{ol}$ & 25 & 3.3 \\
\hline & $"$ & 17 & $03: 38: 48$ & 38.8 ०N, 23.4 of & 90 & 2.7 \\
\hline & $n$ & 19 & $02: 11: 29$ & 37.8 ०N, $23.40 \mathrm{~N}$ & 30 & 2.7 \\
\hline & $"$ & 25 & $0.4: 19: 20$ & 38.1 "N, $23.0 \mathrm{o}]$ & 70 & 2.6 \\
\hline 1969, & Jitll. & 14 & $07: 11: 11$ & $38.7^{\circ} \mathrm{N}, 23.6 \mathrm{a}$ & 80 & 3.1 \\
\hline & & 17 & $0 \mathrm{~s}: 35: 28$ & 37.7 oN, 23.2 of & 50 & 4.0 \\
\hline
\end{tabular}


Talsh III (eont.)

\begin{tabular}{|c|c|c|c|c|c|}
\hline Jate & & O) rigin & Jae:ltion & $\begin{array}{c}\text { Distanee } \\
\text { km }\end{array}$ & $\begin{array}{c}\text { Magniturfe } \\
M_{L}\end{array}$ \\
\hline I969, Iar. & $\begin{array}{r}18 \\
23 \\
24 \\
25 \\
29 \\
13 \\
17 \\
18 \\
18 \\
23 \\
25 \\
25 \\
11 \\
20 \\
20 \\
25 \\
25 \\
25 \\
83 \\
13 \\
4 \\
30 \\
31 \\
7 \\
21 \\
25 \\
27\end{array}$ & 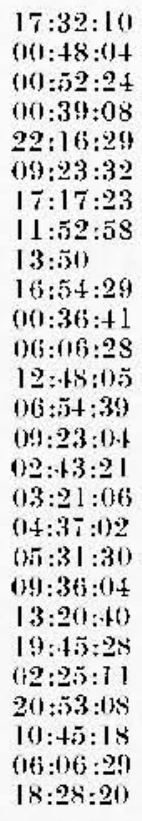 & 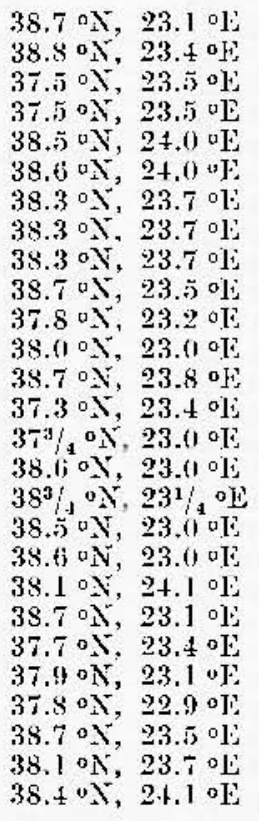 & $\begin{array}{l}100 \\
90 \\
80 \\
60 \\
50 \\
15 \\
30 \\
30 \\
30 \\
30 \\
80 \\
50 \\
60 \\
80 \\
80 \\
85 \\
90 \\
90 \\
95 \\
85 \\
35 \\
95 \\
50 \\
50 \\
70 \\
75 \\
75 \\
15 \\
50\end{array}$ & $\begin{array}{l}3.7 \\
2.9 \\
2.7 \\
3.1 \\
2.4 \\
3.7 \\
2.1 \\
2.1 \\
1.9 \\
2.8 \\
2.4 \\
3.4 \\
3.1 \\
2.9 \\
2.9 \\
2.7 \\
2.7 \\
2.7 \\
3.3 \\
3.7 \\
3.2 \\
2.5 \\
2.9 \\
2.8 \\
3.4 \\
2.5 \\
2.0\end{array}$ \\
\hline
\end{tabular}

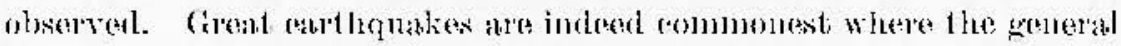
level of seismicity is high but oreasionally they ocellt in otluer regions whore the genemb level of sejmisity is pretty low (18). The Jislun eathouke of Sovember 1, 17is), with $1 />8$, 2 , the Now Mambir (Missonri) entlequalies on Ivecember 18, 18.1., Jamury 23 and Feh-

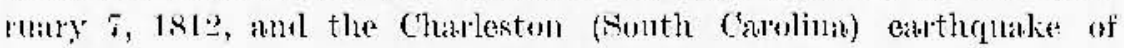

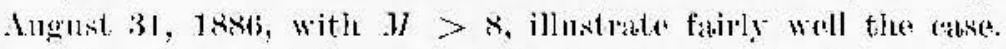

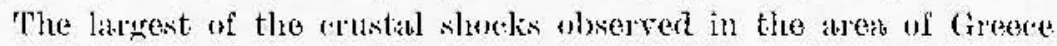

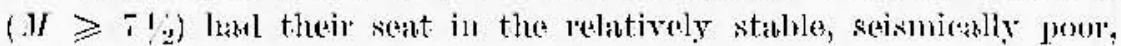
rigrid erystalline mass, in the interior of the mobile Mpine orogentid:



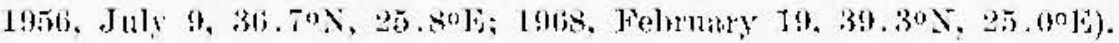

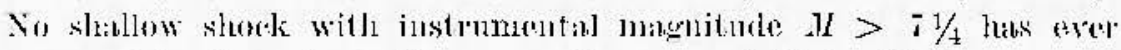

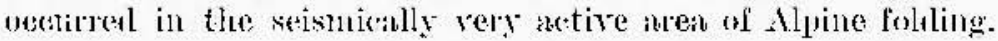


It is worth noting that the najor shallow gathotumes in the

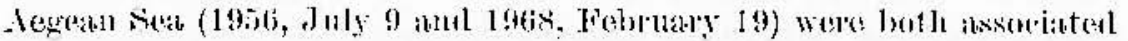

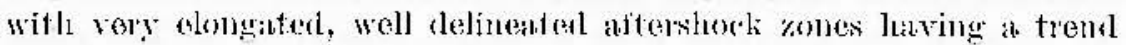

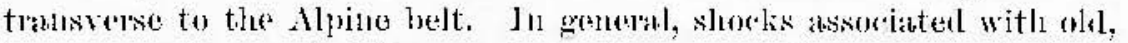

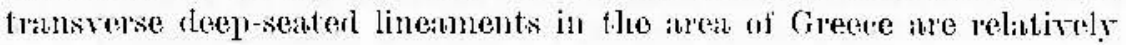
greater but less frequent than those getetionly commerter with longitudinal strustural features of the mea.

\section{CONOTRIGNS.}

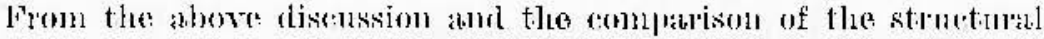

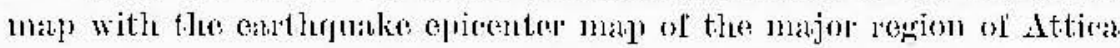
ane might, be allowed to dow the lolluwing eomelusions:

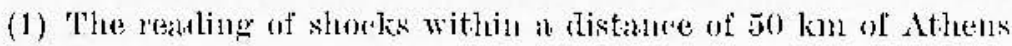
is essentially complecte down 10 magnitule 1.5 ; average mumber of expected abd observed shogks with $y \geqslant 1 / 2$ ber year 127 and 99 , resipectively.

(2) The thereskola ol reliable atertion within a rlistance of $100 \mathrm{~km}$ of Sthens is about $M=\geq .0$; aveage number of expectet and olstrved shoeks with $M \geqslant 2.0$ per year 206 and 176 , respestively.

(3) The lower bermling of the stratght lines representing roures

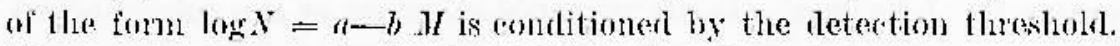
The maximum magnitude theshold is time dependent.

(1) The "one per year" earthruble $M$ is a more reliable metasure of seismicity than the constant $a$ of the $Y(M)$-retation. The

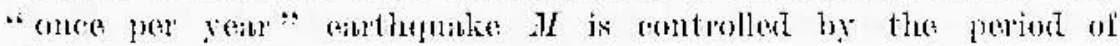
observation mueh less than the constant $a$.

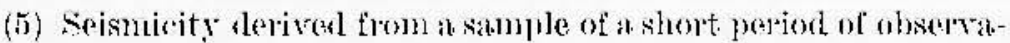

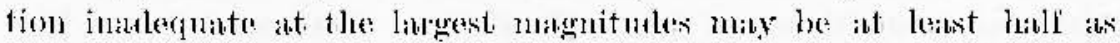

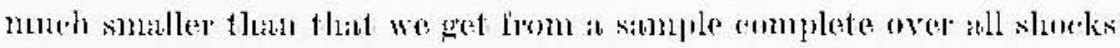
recorrital in a long periont of moservation.

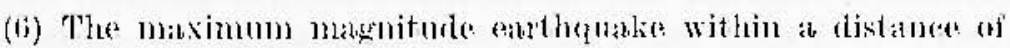

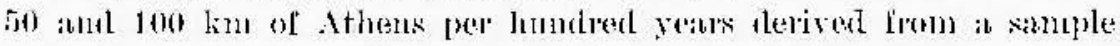




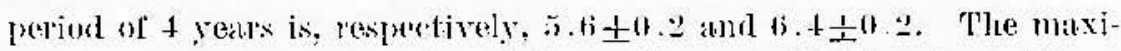

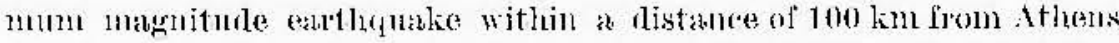

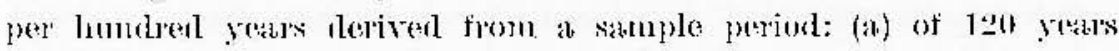

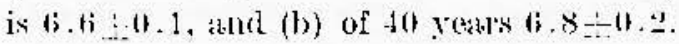

(7) Tho antive enthquake foci por surface nut in thu sub-

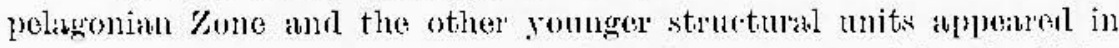
the major region of atticat ontmumber those appenred in the P'elagontan Kono.

(8) The distribution of earthquake for.i in the Snbpelagonian zone ind the other younger structural units of Attica is nexply unitorm and roluctant to tle surface disilocation.

(9) The antive cathoullate fori in the fanlt-bounderl banin of Attica tend to cluster at the northern and soutleme ontlotis of the basin.

\section{ACKNOWLEUGH}

The anthor is much indebted to T) George Marinos, professor for Geology and Palanontology at tho Luiversity of Atlens, for reviewing the geological setting of Attira and ollering ronstructive suggestions, and to Dr. Jolm Drenkopoulos, principal assistant at the Seismological Laboratory of Athens University, for remaling critically the manuscript. Many thanks ane due to Tr. Nick Delibasis, assistant at the Seismologion Iustitute of National Observatory of Athens, for compiling the local shorks missed from the routine realing of tho Wool-Aurlerson reorolings. Thu anthor's thankis are also extenderl to Miss Maria Iyyra, assistant at the Seismologianl Laboratory of the Eniversity of Athens, for her hatrd work in realing all locell slueks rocorded by the Beniuli vertical insirument at Athens, as well as in ranying ont the least-squares solutions for the $N(A f)$-relations of all uned data. The resatarels reporterd in this docmment hat been partially sponsored by

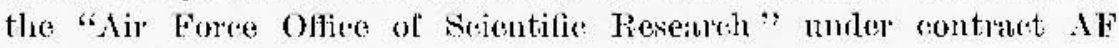
61(05:)-s03 through the "Litropean Office of Aerospace Research

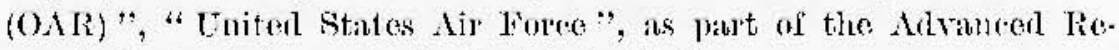
semroh Projuts Areney's Project Fela Unilorm. 


\section{RLFERENClS}

(') Avbons is. La tectonique de la Méditemanér moyenne et les sáismes. "Bull. Soc. Gisol. de France", 7ó série, 5, pp, 1124.1129, (1963).

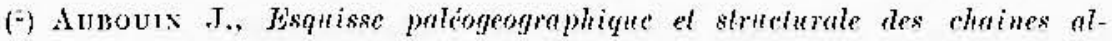
pines de la Medilermuée moyenue. "Geol. Rumkschan", 53, IIeft 2. p). $480.534,(1964)$.

$\left({ }^{3}\right)$ Bodecinter I. and Papadeas G., Tectonie Aerial Interpretation in the Meditermean Region Exentified by the Metamorphic Seriss of Eastern (ireece, Near Marathon. "Photogrammetria", 23, pl), 201-214, (1968).

(4) Bruxix. T., Contribution à l'étude géologique du Pinde Septentrional at d'tene partie de ln Macedoine Occidentule, "Anuls. Gísol. Pags Hell ", 7, Athènes $1956)$.

(5) Bruxe X. J., Seismic Moment, Seismicily and hate of Stip nong Major Faull Zones, "Jowr. Geoph. Res.", 73, 2, pp. 777.784, (1968).

(6) Gamaxopoudos $G$. A, On Quantitative Determination of Earhquake Rish. "Nin1, di (teof.", 21, 2, 1p). 193-206, (1968).

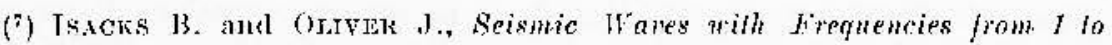
100 Gycles per Srond Recorded in a Deep Wine in Northern Xetr Jersey. "Bull. Seism. Soc. Am.", 54, pp. 1941-1979, (1964).

(8) Kansin V., Wngminde-Frequency Relation and Seinmic Aelirity in Diffrem Regions of the Europern Arr. "Bull. Intern. Inst. Seism. Earth. ling." ", 1, pp. 9.32, (1964).

(?) Kansik V., Magnilude. Frequency and Fusmy of Earthqualies in the European Area. "Travaux de l' [not. Geoph. de l'Aeal. Tohecoslavique des ficiences", 13, 222, pp. 247-272, (Pralia. 1966).

(1i) Kansis Y., Seismicity of Europe. Progress Repurt 1V, Misueotraphed (1'ruhu. 1968).

(11) Kivess K., les plissemenls d'áge primaire dans la région centrale de la mer Egie. "Congrès Gínl. Intern." 13, pp. 5̆ 1.-583 (Liège. 1923).

(12) Manisos (4., Zur Gliederming Ostgriechemlands in tektomischen Zonen. "Genl. Rumklschau", 46. 11). +21-426. (1957).

(13) Hanisos G., Palneontologic and Stmagraphic Tnvestigations in Eastern Continental Grece, " Bull. Geul. Sors. Grece", 4, pp. 14-28. (A thens, $1961)$.

(14) Mryaura $\mathrm{S}$, Magminde-Frequency Relations and its Bearings to Geotertonirs. "Jroc. Japan Ar.", 38, 1, pp. 27-30, (1962).

(15) Moril K.. Stuly of Elastic Shook caused by the Frature of Helerogeneous Waterials and its Relation to Earthquale I'Tenoment. "Bull. Earthr. Res. Inst." 40. pp. 125.173, 831-853, (1962); 41, pp. 615.668, (1963), 
(6) Parakngopoctos G., Die Umrandung des Athiseh-Jyhladisehen Massivs im Gebiet zwischen Penteliton -uwd Pamesgehirge. "Anuls. Gool. Pays Hell. ", 14, pp. 305ั-323, (1963).

(17) Rwxz C., Die Vorneggene Stratigraphie tiriechentands. (A geological treatice with a long list of related references). [nst.-(Geol. and Sul. surface Research, (Athens, 1955).

(18) Riciter C., Elementary Seismoloyy, San Franciseo, 1958.

(19) Rizxicumsco J. V. ant Neusesoy I. I., A Detaled Study of the Seismic Regime in the Carm Epicentral Region. "Ann. di Geof.", 14. 2, pp. 173. $186,(1961)$.

(20) Rrzichtico J. V., Problems in Detailed Studies of hegional Seismicity. "Tzvestia Acar. Sci. USSR", English Fi., 7, pp. 409-419, (1969).

(1) Visocirabov s. D, Esperimental Sludy of the Distribution of the $\mathrm{N}_{\text {wmber }}$ of Fratures in respect to the Energy Liberated by the Destruction of Rochs.

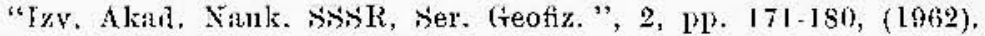

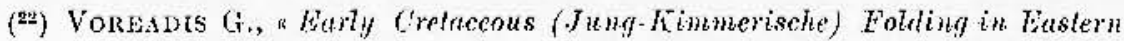
freece and Phases of the Alpine Orofenesis in Grece". Dissertation (Athens, 1937). 